Discussion Paper No. 05-13

Workers into Managers -

Developing Leadership Competence of Production Unit Managers

Christoph Rappe and Thomas Zwick

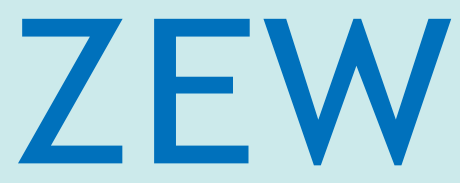

Zentrum für Europäische Wirtschaftsforschung $\mathrm{GmbH}$

Centre for European

Economic Research 
Discussion Paper No. 05-13

\title{
Workers into Managers - Developing Leadership Competence of Production Unit Managers
}

\author{
Christoph Rappe and Thomas Zwick
}

Download this ZEW Discussion Paper from our ftp server:

ftp://ftp.zew.de/pub/zew-docs/dp/dp0513.pdf

Die Discussion Papers dienen einer möglichst schnellen Verbreitung von neueren Forschungsarbeiten des ZEW. Die Beiträge liegen in alleiniger Verantwortung der Autoren und stellen nicht notwendigerweise die Meinung des ZEW dar.

Discussion Papers are intended to make results of ZEW research promptly available to other economists in order to encourage discussion and suggestions for revisions. The authors are solely responsible for the contents which do not necessarily represent the opinion of the ZEW. 


\section{Non-technical summary}

A key position in high performance work organizations is the production unit manager. His or her performance has an immediate impact on the bottom line of the organization and on the employees who actually produce the goods and services. The production unit manager has traditionally fulfilled the role of a technical expert who received orders from upper management and passed these orders on to shop-floor personnel. In self-managed production units, this position receives considerably more responsibilities and broader spans of control: Production supervisors are responsible for discrete areas on the shop floor. Here, they are accountable for quality, output levels, planning, controlling, cost efficiency, and improving production processes. In addition, many responsibilities are transferred from specialist departments to the production line and become part of the supervisor's job. Therefore, the supervisor's role in a selfmanaged teamwork structure is more managerial, shifting from traditional supervision and control to greater emphasis on coaching and facilitation.

The new role demands a higher level of competence from production supervisors, especially in the areas of interpersonal and leadership skills. Few studies have examined the new situation of first-line managers in high performance work organizations. This present study sheds light on the supervisors' situation in autonomous production units. It identifies typical areas of competence problems and their relevance to outcomes such as acceptance as a manager by subordinates and superiors, quality of the interaction with subordinates and superiors, and job satisfaction. In addition, it examines how far the identification with the managerial role and the awareness of expectations towards their position are determinants of those outcome variables. Finally, this present study analyses the impact of a leadership development programme for first-line managers on leadership competence, leadership identity, and the outcome variables.

Results indicate that the managers have difficulties with their new leadershiprelated tasks. Higher levels of leadership competence were found to be associated with better acceptance as a manager by superiors, but not by subordinates, better interaction with both subordinates and superiors, and with higher job satisfaction. Identification with the managerial role and the awareness of expectations were also shown to be relevant for several of these outcome variables.

The enterprise conducted a leadership programme for first-line managers that consisted of three modules: a leadership workshop, a teambuilding workshop, and five individual coaching sessions to promote transfer. Supervisors could not select if they wanted to participate in the programme but participation was bound to the exogenous affiliation with one of several equivalent organizational units. This provided a perfect quasi-experimental research condition. A comparison of programme participants with other first-line managers shows that the programme had measurable positive effects on leadership competencies-especially communication and conflict solving — and partly improved identification with the managerial role. 


\title{
Workers into Managers - Developing Leadership Competence of Production Unit Managers
}

\author{
Christoph Rappe and Thomas Zwick
}

E-mail: zwick@zew.de

Centre for European Economic Research (ZEW)

February 2005

\begin{abstract}
This study analyses the competence gaps of lower-level managers in a typical manufacturing plant in Germany that had recently introduced a teamwork structure. Results indicate that the managers have difficulties with their new leadership-related tasks. Higher levels of leadership competence are found to be associated with better acceptance as a manager by superiors, but not by subordinates, better interaction with both subordinates and superiors, and with higher job satisfaction. Finally, a quasi-experiment shows that a combination of workshops and individual coaching had measurable effects on leadership competencies and partly improved identification with the managerial role. In terms of methodology, a new format of self-assessments is suggested for a more valid measurement of competencies.
\end{abstract}

Key-words: Leadership skills, first line managers, training, experiment JEL-codes: C93, J24, M12

\section{Acknowledgements}

We thank Nicole Guertzgen and Gaby Wunderlich for helpful comments and especially Sonja Kurz and Janin Ennes for important advice and support throughout the project. 


\section{Introduction}

High performance work practices are increasingly being introduced into the workplace. These practices are characterized by augmented worker participation and involve changes in work design, decision authority, pay systems, and skill levels (Appelbaum, Bailey, Berg, \& Kalleberg, 2000; International Labour Office, 2002). Positive effects on performance and productivity have repeatedly been shown, which justifies the term high performance work practices (Appelbaum et al., 2000; Batt, 2001; Ichniowski, Kochan, Levine, Olson, \& Strauss, 1996; Wolf \& Zwick, 2002).

The study discussed in this article examined high performance measures that affect the organisation of work, such as teamwork, involvement of nonmanagerial staff, and self-managed work groups. Previous research has found that organisational efficiency is improved through such measures because the greater technical expertise and knowledge of work conditions enable shop-floor personnel to solve problems at the production level more efficiently (Appelbaum et al., 2000; Lowe, 1993). Moreover, knowledge spill-over between group members is enhanced, which further increases benefits over time (Levine \& D’Andrea Tyson, 1990). In addition, high performance work practices result in lower managerial costs as the pay of first-line managers is usually only slightly above worker level (Colvin, Batt, \& Katz, 2001; Osterman, 2000). For these reasons, many firms, especially manufacturing firms, have introduced selfmanaged production units in recent years (Finegold \& Wagner, 1999).

A key position in high performance work organisations is the production unit manager. His or her performance has an immediate impact on the bottom line of the organisation and on the employees who actually produce the goods and services (Daniel, 1992). The production unit manager, or supervisor, ${ }^{1}$ has traditionally fulfilled the role of a technical expert who received orders from upper management and passed these orders on to shop-floor personnel. In selfmanaged production units, this position receives considerably more 
responsibilities and broader spans of control: Production supervisors are responsible for discrete areas on the shop floor. Here, they are accountable for quality, output levels, planning, controlling, cost efficiency, and improving production processes (Barton \& Delbridge, 2001; Batt, 2004; Finegold \& Wagner, 1999; Lowe, 1993; Sheldrake \& Saul, 1995). In addition, many responsibilities are transferred from specialist departments to the production line and become part of the supervisor's job (Lowe, 1993). Therefore, the supervisor's role in a self-managed teamwork structure is more managerial, shifting from traditional supervision and control to greater emphasis on coaching and facilitation (Batt, 2004; Finegold \& Wagner, 1999).

The new role demands a higher level of competence from production supervisors, especially in the areas of interpersonal and leadership skills (Barton \& Delbridge, 2001; Batt, 2001; Lowe, 1993; Manz \& Sims, 1987; Stewart \& Manz, 1995). Sheldrake and Saul (1995) state that "there has been a significant increase in the importance of leadership, communication, interpersonal and learning competencies as first line managers must establish, explain and win team members' commitment to objectives and priorities, more actively deal with conflict and poor performance, consult with clients and other teams and cope with a variety of new demands" (p. 667).

Having served in the technical role of a semi-skilled checker for years or even decades, and faced with unfamiliar challenges, many supervisors are experiencing job insecurity (Vettermann \& Dorando, 2003). Lowe (1993) reports that 75 percent of supervisors in an American automobile plant admitted that in spite of completing a training programme they felt inadequate or incapable of fulfilling all the requirements of the new role. Schmidt-Braße, Rätz, and Heier (2001) describe a development programme for production supervisors in a German steel factory that covered topics such as the supervisor's role in the company and leadership and communication skills. Participation was voluntary, but after 2 years, nearly 100 percent of the target group had taken part, which confirms that the training met a strong need. 
Few studies have examined the new situation of first-line managers in high performance work organisations. Most studies that analyse the consequences of the introduction of high performance workplaces concentrate on the increase in organisational efficiency, especially the effects on pay and performance, while the challenges and problems of those affected are not addressed (Batt, 2004). This present study sheds light on the supervisors' situation in autonomous production units. It identified typical areas of competence problems and their relevance to outcomes such as acceptance as a manager by subordinates and superiors, quality of the interaction with subordinates and superiors, and job satisfaction. In addition, it examined how far the identification with the managerial role and the awareness of expectations towards their position are determinants of those outcome variables. Finally, this present study analysed the impact of a leadership development programme for first-line managers on leadership competence, leadership identity, and the outcome variables. In the following sections, the research hypotheses are outlined.

\section{Competence Gaps}

In view of what production unit managers have learned and have been doing for years, and in view of what is required from them after the introduction of self-managed teams, in this study, it was hypothesized that production unit managers have more difficulties with the new, leadership-related tasks than with the traditional tasks of technical support and doing one's own job. Leadership tasks include active communication, delegation, giving feedback, dealing with difficult subordinates, and acting as a representative for the unit.

Hypothesis 1: Production unit managers have more difficulties with leadership-related tasks than with traditional tasks.

Although the need for closing the competence gap might seem obvious, employees often receive little training for their new responsibilities. It appears that little has changed since the 1980s when researchers found that first-line supervisors, who were usually selected from the worker ranks, received a minimum amount of training for their new jobs (Bittel \& Ramsey, 1983; Crumb, 
1981; Gilmour \& Lansbury, 1986). Sheldrake and Saul (1995) state that "front line managers have the most immediate impact on productivity and quality output of the work force [but] the majority of them are not being prepared for [future] challenges" (p. 33). A human resource manager in Barton and Delbridge's (2001) study described his company's training measures in the following way: "We do some orientation with them, a little bit of what to expect and things like that" (p. 469). These observations lead to the conclusion that in spite of the increased need for training (Barton \& Delbridge, 2001) little attention has been paid to the competence gap of supervisors.

\section{Leadership Development for Production Unit Managers}

In most cases, leadership training has been directed at upper management. In fact, leadership training for first-line managers has only recently become an issue. Few training programmes for first-line managers have been conducted, and even fewer programmes have been evaluated empirically. However, two studies (Kleinau, 2002; Vettermann \& Dorando, 2003) did collect informal feedback from first-line managers. Kleinau (2002) found that after an 18-month, multimethod development programme foremen felt they were part of the company's management, had a better understanding of their responsibilities, and were able to perform their jobs more professionally. Vettermann and Dorando (2003) examined the effectiveness of a programme based on workshops, collegial coaching, and learning projects. They found that participants were better able to identify with their managerial role, had a clearer understanding of their job, experienced increased self-confidence, were more aware of their strengths and weaknesses, and were able to take a more active leadership role.

The study discussed in this article empirically examined a leadership training programme for production unit managers in order to investigate whether this programme helped participants better identify with and perform their managerial role.

Hypothesis 2: Leadership development has a positive impact on leadership competence. 


\section{Effects of Leadership Competence}

Competencies are underlying characteristics of employees that result in effective or superior performance in their job (Boyatzis, 1982), which implies that they are causally related to effective job performance. Indeed, leadership competence has repeatedly been shown to influence the performance of a production unit (Wilson et al., 1990; Yammarino \& Bass, 1990). For example, Daniel (1992) shows that 7 of the 13 competencies in his model significantly distinguished high-performing supervisors from randomly selected supervisors. Moreover, the out-performing supervisors had higher overall scores than randomly selected control participants.

In the study discussed in this article, the focus was not on how leadership competencies affect productivity, but how leadership competencies affect the production process. This perspective complements existing research on productivity and provides clues for interventions on a level that is more accessible than objective output data. In addition, such effects are of considerable importance for a first-line manager's sense of well-being, which may constitute a noteworthy value in itself. Ultimately, these process-related variables are also linked to both individual and team performance (Hall, 2004; Hoegl \& Gemuenden, 2001; Messe, Kerr, \& Sattler, 1992; Petty, McGee, \& Cavender, 1984).

Three such effects were considered in this study. First, first-line managers often have problems being accepted as managers both by their subordinates and their superiors (Lowe, 1993). It can be hypothesized that their acceptance will partly depend on the competence they exhibit as a manager (Javidan, 1995). Second, able managers might establish a smoother workflow with subordinates and superiors. Third, it can be assumed that the experience of being unable to deal with the challenges of a job causes emotional distress and decreases job satisfaction.

Hypothesis 3: The level of leadership competence has a positive impact on acceptance as a manager by subordinates (H3a) and superiors (H3b), quality of the interaction with 
subordinates (H3c) and superiors (H3d), and job

satisfaction $(\mathrm{H} 3 \mathrm{e})$.

\section{Effects of Leadership Identity}

The understanding of and feeling about one's role may be critical for job performance and could, therefore, also be regarded as a competency (Boyatzis, 1982). However, this is a conceptually different category. Whereas the competencies discussed above refer to the ability to deal with specific situations, role identity is about the overall cognitive and emotional representation of the job within the individual. Therefore, both concepts are considered separately.

The first-line manager's position as a "man in the middle" who has come up from the ranks but is not part of management constitutes a critical challenge in self-managed work groups (Lowe, 1993). Identification with the managerial role has consequences on the outcome level. Halpern (1961) and Grimm and Dunn (1986) found that supervisors who identified with management tended to be more satisfied. Managers who see themselves as managers and act accordingly will also have a greater probability of being accepted as managers by their subordinates and superiors, and workflow will be smoother because they do not neglect the tasks associated with their managerial role.

Hypothesis 4: Identification with the managerial role has a positive impact on acceptance as a manager by subordinates ( $\mathrm{H} 4 \mathrm{a})$ and superiors $(\mathrm{H} 4 \mathrm{~b})$, quality of the interaction with subordinates $(\mathrm{H} 4 \mathrm{c})$ and superiors $(\mathrm{H} 4 \mathrm{~d})$, and job satisfaction $(\mathrm{H} 4 \mathrm{e})$.

It is important for first-line managers to understand what they are expected to accomplish as a manager. The importance of having role clarity (knowing the tasks and expectations of a job) has been shown in previous research that used both emotional and performance-related measures (Abramis, 1994; Jackson \& Schuler, 1985; Tubre \& Collins, 2000). ${ }^{2}$ In the present study, it was hypothesized that knowing the expectations of superiors and subordinates helps first-line 
managers meet these expectations and ensures that they are accepted as a manager. It was also assumed that role clarity is a prerequisite for harmonious interactions with others in the role set (McGrath, 1976). Finally, the absence of role clarity leads to stress, intrapersonal tension, and lowered job satisfaction (Cooper, Sloan, \& Williams, 1988; Hall, 2004).

Hypothesis 5: Role clarity has a positive impact on acceptance as a manager by subordinates (H5a) and superiors (H5b), quality of the interaction with subordinates (H5c) and superiors (H5d), and job satisfaction (H5e).

In this study, it was hypothesized that taking part in a management development programme and learning methods of managing others might enhance a first-line manager's identification with the managerial role. In addition, reflecting on one's role in an organisation, receiving feedback from others, and being trained for specific tasks are assumed to lead to an increased awareness of expectations and a better understanding of one's role (Vettermann \& Dorando, 2003).

Hypothesis 6: Leadership development has a positive impact on the identification with the managerial role (H6a) and the awareness of expectations (H6b).

The hypothesized model of the causal relationships among the constructs is illustrated in Figure 1. The constructs are expected to fall into three causal levels: (1) intervention, (2) effects of the intervention, and (3) ultimate outcomes (or second-level effects).

\footnotetext{
${ }^{2}$ Some of these studies refer to the construct of role ambiguity, which can be regarded as the antipode of role clarity (Sawyer, 1992).
} 
Figure 1 Model of the Hypothesized Causal Relationships Among the Constructs intervention $\quad \underline{\text { effects }}$ outcomes

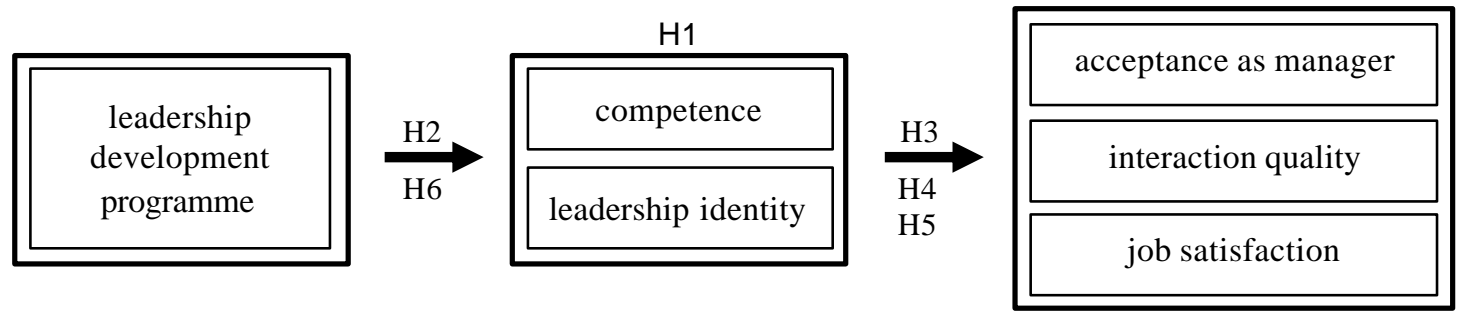

\section{Method}

A quantitative study was conducted in one specific company to test the research hypotheses. The choice of a quantitative study in one company helps to control for variation in firm-level variables, such as corporate culture, business strategy, and human resources policies (Batt, 2001), and it allows the effects of organisational changes and management development to be more accurately identified (Batt, 2004). In addition, confining the study to one company enabled the researcher to approach the entire group of production unit managers and, therefore, avoid selection effects.

\section{The Company}

The research setting was a leading, worldwide supplier of automation technology and a typical example of the highly specialized and international mechanical engineering firms found in Germany. The core activities of the company are the fast, flexible production and assembly of high-quality, tailormade automation products from more than 20,000 components in a variety of modular programmes. The family-owned company employs about 10,000 people worldwide at 250 sites. Beginning in 1995, production was re-organized by introducing self-managed production units, comprising 20 to 100 employees each. Here, one worker from each of the two shifts of each production unit was appointed production unit manager, at a slightly increased salary. There was no formal selection procedure for the appointment of production unit managers. The personnel department picked a member from each group they considered suitable 
for the job. This informal appointment procedure is quite common in German manufacturing (Mason, 2000).

\section{The Production Unit Managers}

Half of the production unit managers who participated in this study were skilled workers who had been trained in the dual apprenticeship system. The apprenticeship programme takes about 3 years and involves practical contents taught in companies and theoretical contents taught in public professional schools (Finegold \& Wagner, 1999). Apprentices obtain virtually no management training. Another third of the managers were master craftsmen ("Meister"). Master craftsmen voluntarily attended additional training, mainly in technical subjects, but also in logistics, business organisation, and instructional techniques during evening courses over 2 years. Some master craftsmen courses provide pedagogical and technical skills needed to coach front-line workers to become effective team leaders (Finegold \& Mason, 1999). Half the managers had worked for the company for 15 years or more. Most of them have been appointed production unit manager when the company re-organized its production units in 1995.

In 2001, the company conducted a worldwide employee survey, which found that production unit managers were experiencing serious difficulties with their role. Therefore, a three-module programme was designed to tackle these problems. This programme included a (1) leadership workshop, (2) teambuilding workshop, and (3) individual coaching to promote the transfer of skills learned in the workshops.

\section{Participants and Data Collection Procedure}

The study was conducted at the main production site of the company in Germany. All 44 production unit managers were asked to complete a written questionnaire. From this group of managers, 24 had participated in the management development programme, while 20 had not yet participated in the programme. Thirty-eight managers (86\%) returned their questionnaires (21 development programme participants and 17 non-participants). Three 
participants had only taken part in one workshop so far. Their questionnaires were marked so that their data could be excluded from the analysis when group adherence was relevant (principle of maximizing variance between groups). Thus, the sample size was $n=18$ for the programme participants and $n=17$ for the non-participants. All participants in the study were male.

The questionnaires were personally presented to the study participants wherever possible (some employees were absent, so one of their colleagues passed on their copy). The purpose of the study was explained, and participation was encouraged by noting that the questionnaire was endorsed by the management and the works council of the company. Basically, the production unit managers were told that little was known about the effects of organisational changes, such as the introduction of self-managed production units, on the people concerned and that this study would shed light on that issue. Following consultation with the company, such a personal, non-standardized instruction was chosen as the best way to ensure the trust and co-operation of the particular target group. The briefing was entirely neutral regarding the contents of the questionnaire: Any question about hypotheses was answered by saying that nothing was known yet. The participants had 2 weeks to fill out the questionnaire, and the company allowed them to do this during working hours. The questionnaire could be placed anonymously into a sealed box set up at a central place in the plant. Two reminder emails were sent to all participants before the box was removed after 3 weeks. Both the study participants and the company's management received feedback about the results.

\section{Measuring Leadership Competencies}

He or she has the richest amount of information about him- or herself. Not only is the behaviour sample much more comprehensive, but the information is also remembered in a more lasting, accurate, and differentiated way (Hossiep \& Paschen, 1998). However, self-ratings have often been criticized for low validity. Extensive research has demonstrated that the self-assessment of skills is moderately related to performance criteria (Ash, 1980; DeNisi \& Shaw, 1977; Ford \& Noe, 1987; Levine, Flory, \& Ash, 1977) and at least as predictive of 
outcomes such as job performance as other sources of information (Mabe \& West, 1982; Shrauger \& Osberg, 1981). Self-assessments have been found to be more lenient than assessments by third parties (Holzbach, 1978; Kirchner, 1965; Lawler, 1967; McEnery \& McEnery, 1987; Meyer, 1980; Thornton, 1968); however, they have also been shown to exhibit less halo ${ }^{3}$ (Klimoski \& London, 1974; Lawler, 1967; McEnery \& McEnery, 1987; Parker, Taylor, Barrett, \& Martens, 1959; Thornton, 1980). Thus, self-ratings may be an important complement or even preferable alternative to supervisor ratings (Bandura, 1978; McEnery \& McEnery, 1987), especially when discrimination among different competencies is sought.

When self-assessments ae used, it is desirable to reduce bias as much as possible. According to several studies (Bittel \& Ramsey, 1983; Mabe \& West, 1982; McEnery \& McEnery, 1987; Morano, 1973; Morrison \& Bies, 1991; Shrauger \& Osberg, 1981; Thornton, 1980), the amount of bias in self-ratings varies considerably, and this variability is influenced by four factors:

- clarity of the constructs (Thornton, 1980). The more abstract an item, the more a participant's understanding varies, which brings error variance into play;

- rating scale (Thornton, 1980). Often, the participant is asked to assess his or her competence on a rating dimension that is either not clear or not appropriate;

- motivation for self-enhancement (Mabe \& West, 1982). The bias is presumably lower when an individual does not expect substantial gains from positive ratings: In a performance appraisal, bias will tend to be higher than in a training needs analysis or in a "for research only" situation (McEnery \& McEnery, 1987; Shrauger \& Osberg, 1981; Thornton, 1980). The external motivation of rewards for high ratings might be complemented by an internal unwillingness to admit personal shortcomings; and

\footnotetext{
${ }^{3}$ Halo denotes the insufficient discrimination among aspects of behaviour and
} 
- accuracy of the self-image (Morrison \& Bies, 1991). A person's self-rating cannot be more accurate than his or her self-image. Bittel and Ramsey (1983) observed that supervisors often have misplaced confidence in their ability to handle difficult and sensitive managerial situations. However, Morano (1973) claims that employees are aware of their skill weaknesses and performance deficiencies.

Traditional competency measurements have often not sufficiently acknowledged these measurement problems. Particularly in studies on management competencies, self-assessments often appear to veil decisive differences. In several studies, no deviations were found among sub-groups when self-assessments were used, while external assessments (such as subordinate assessments) differed significantly (Daniel, 1992; Wilson, O'Hare, \& Shipper, 1990). This may be due to the measurement scales that were used.

Traditional scales often have participants directly rate their confidence or ability (e.g., not confident to very confident [Bittel \& Ramsey, 1983]; level of ability high/average/low [Klagge, 1998]). Unfortunately, this wording tends to activate the motive for self-enhancement. In addition, it is unclear which characteristics participants use to assess their ability: amount of experience, feedback on the last application, and so forth. It appears that the desire for selfenhancement (Mabe \& West, 1982) and the ambiguity of rating scales (Thornton, 1980) are two important sources of bias.

Many studies have used frequency ratings (e.g., rarely or never to very frequently, if not always [del Gaizo, 1984; Latham, Fay, \& Saari, 1979; Posner \& Kouzes, 1990; Yukl, Wall, \& Lepsinger, 1990]). However, frequency is independent of mastery, as Shipper and White (1999) illustrate in their study. Furthermore, according to Boyatzis' (1982) definition of competencies, a job competency clearly represents an ability, is "what he or she can do, not necessarily what he or she does" (p. 23). Therefore, competence should be measured in terms of mastery.

predominance of an overall impression. 
In the study discussed in this article, a new scale format was developed and tested. This scale aimed to provide a more valid way of measuring competencies through self-assessments. Instead of asking about level of competence or frequency, participants were asked how often they find it difficult to do certain things. This resembles a frequency scale. However, it does not refer to the frequency of a behaviour, but to the proportion of difficult situations. In the introduction, it is clearly stated that such difficulties can have different reasons. Thus, the participants have an "excuse" not to tick the top value because they can attribute difficulties to the working conditions or other factors that might be hindering them. The scale is based on the assumption that a highly competent manager would be able to execute these crucial management tasks even under difficult circumstances. Hence, the scale presented here evades the motive of self-enhancement by providing an excuse for having difficulties (the attribution to external causes), and it offers a clear rating scale that is appropriate to the issue (mastery, not frequency).

In order to avoid unclear constructs-another source of bias discussed by Thornton (1980)—competencies should be formulated on a specific level. This is particularly important when working with people who are not used to reflecting on their work in abstract terms. Therefore, the competencies to be rated in this study were general enough to be applicable to all relevant positions but clearly associated with concrete activities.

Besides considering specific competencies, the overall level of competence in a specific job is often of interest. To this end, the values of a set of competencies need to be aggregated. As Daniel (1992) explains, the overall level of competence reflects the fact that a weakness in one competency may be compensated by strengths in other competencies.

The simplest way to achieve aggregation is by using the unweighted mean across individual competencies. In all jobs, however, there are some competencies that are more important than others. Therefore, a weighted aggregate more adequately reflects the overall level of competence. The common way of multiplying the values with their weights and dividing the sum of these 
products by the sum of the weights works well for weights that are spread over a large scale. When this is not the case and differentiation between more and less important competencies is still sought, another formula may be used that closely discriminates between small differences among weights: Here, the unweighted mean first determines the arithmetic centre of the single values. Then, it is adjusted for the differential importance of the single values by moving it closer to those values that are of greater importance by adding the weighted deviations of the single values from the individual's arithmetic mean:

(1) $\quad m_{w}=m_{u}+\sum_{i=1}^{k}\left(c_{i}-m_{u}\right) \cdot w_{i}$

with $m_{w}$ the participant's weighted mean across all competencies, $m_{u}$ the participant's unweighted mean across all competencies, $k$ the number of competencies in the model, $c_{i}$ the participant's level of competence on competency $i$, and $w_{i}$ the weight of competency $i$, namely the mean assessment of the importance of competency $i$ across all participants scaled to a range of 0 to 1 .

The best estimate available for the "true" importance of a competency is the mean importance rating of all participants, assuming that certain competencies are more important for successful job performance than other competencies for anyone doing this job, and regardless of whether a specific individual has realized the importance or not. Therefore, the average rating, not individual ratings, are used for weighting in this study.

\section{The leadership development programme}

The leadership development programme was implemented in the summer of 2002 and involved the production unit managers and partly also their teams of shop-floor workers. The programme was designed to impart leadership competencies, particularly in the area of conflict resolution, enhance role identification of the managers, and improve co-operation within the teams. The programme consisted of three modules: (1) a leadership workshop (2 days for all production unit managers), (2) a teambuilding workshop (2 days for production 
managers plus six members from each team), and (3) five 1-hour individual coaching sessions to promote the transfer of skills.

In both workshops, theoretical input was rather short; the focus was on group work and moderated discussions designed to promote an exchange of experience. In addition, action-oriented methods, both indoor and outdoor, were used to challenge participants with work-related problem solving or interaction tasks. The coaching was offered by an internal consultant and based on methods used in systemic consulting and neurolinguistic programming (NLP). On average, the treatment participants had 3.37 coaching sessions $(S D=1.57)$ at the time of the study. Only five production unit managers chose individual sessions; most of the managers attended their sessions with the colleague who supervises the other shift in their unit.

Recently, development programmes have started to focus on the needs of the individual. As coaching matches this trend, it has become an important method of management development (Dorando \& Grün, 2004; Finger-Hamborg, 2002; Frisch, 2001; Wasylyshyn, 2003). Coaching is based on dealing with concrete problems encountered on the job. It provides a test-operate-test-exit frame in which the trainee is assisted by the coach until he or she has mastered a specific skill. This format, with its feedback-controlled course and its focus on real-life situations, increases the probability that the learning contents transfer to the job (Schreyögg, 1995).

As a result of coaching's ability to enhance competence development, it has become an integral part of personnel development in many companies (Spies, 2004). However, most coaching occurs at the upper management level. Although Dorando and Grün (1993) show that coaching can also benefit first-line managers, there are three reasons why this method of development training has not been considered appropriate for this group. First, coaching mai nly focuses on the development of social, communication, leadership, and conflict resolution skills (Dorando \& Grün, 2004; Wales, 2003). These skills have not been regarded important for supervisors. Second, one-on-one coaching is expensive, and personnel development for supervisors, in general, has not been considered worth 
the investment (Barton \& Delbridge, 2001). Third, coaching is often viewed with scepticism by first-line managers (Dorando \& Grün, 1993; Finger-Hamborg, 2002; Vettermann \& Dorando, 2003).

Given the success of coaching as a method of development training for upper level managers (Olivero, Bane, \& Kopelman, 1997), it seems likely that this method would help first-line managers identify themselves as managers and become more competent leaders. As a result of the changing nature of the supervisor's role, and based on the positive experiences described by Dorando and Grün (1993) and Finger-Hamborg (2002), the programme examined in this study deliberately employed the method of coaching for developing the first-line managers.

\section{Quasi-Experiment}

At the time of the study, the leadership programme had been implemented in two of the four production units, which are all equivalent regarding tasks, recruiting methods, and staff profiles. Participation in the leadership programme was obligatory for first-line managers of the first units. The control group participants were scheduled to take the management development programme, but at the time of the study, they had not received any training. This provided an ideal control group condition because managers could not select if they wanted to participate in the programme, but participation was bound to the exogenous affiliation with one of several equivalent organisational units.

Extensive investigations were conducted on correlations between group affiliation and other variables. Most personal characteristics were not significantly different in the two groups (see Table 1). Those characteristics that were significantly different did not correlate with the competencies or any other outcome variables. Therefore, any differences between the treatment and control group can, with a sufficient level of confidence, be attributed to participation in the training programme. 
Table 1: Characteristics of Treatment and Control Group

\begin{tabular}{|c|c|c|c|c|c|c|c|c|c|c|c|}
\hline \multirow{2}{*}{\multicolumn{2}{|c|}{ Item }} & \multicolumn{3}{|c|}{ Treatment } & \multicolumn{3}{|c|}{ Control } & \multicolumn{4}{|c|}{ Difference } \\
\hline & & $\mathbf{M}$ & SD & $\mathrm{n}$ & $\mathbf{M}$ & SD & $\mathrm{n}$ & M & SE & df & $t$ \\
\hline \multirow{4}{*}{ 용 } & $\begin{array}{l}\text { How many subordinates are you } \\
\text { responsible for? }\end{array}$ & 74.36 & 17.21 & 14 & 40.25 & 22.59 & 16 & 34.11 & 7.42 & 28 & $4.60^{\star \star \star}$ \\
\hline & $\begin{array}{l}\text { With how many of your subordinates are } \\
\text { you in touch w ith outside work? }\end{array}$ & 2.86 & 3.70 & 18 & 1.06 & 1.85 & 17 & 1.80 & 1.00 & 33 & 1.80 \\
\hline & $\begin{array}{l}\text { With how many of your colleagues are } \\
\text { you in touch with outside work? }\end{array}$ & 1.69 & 1.45 & 18 & 0.76 & 1.15 & 17 & 0.93 & 0.44 & 33 & $2.10^{*}$ \\
\hline & $\begin{array}{l}\text { How would you assess the work pressure } \\
\text { in your area, as compared to other areas } \\
\text { in the company? } \\
-10 \text { (much lower) } \ldots+10 \text { (much higher) }\end{array}$ & 4.72 & 3.94 & 18 & 3.53 & 4.12 & 17 & 1.19 & 1.36 & 33 & 0.88 \\
\hline \multirow{4}{*}{ 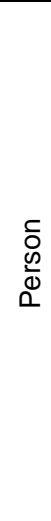 } & $\begin{array}{l}\text { Your age } \\
1(<30) \ldots 7(>60)\end{array}$ & 3.57 & 1.02 & 14 & 3.50 & 1.10 & 16 & 0.07 & 0.39 & 28 & 0.18 \\
\hline & $\begin{array}{l}\text { How long have you been in your current } \\
\text { position? } \\
\text { in years }\end{array}$ & 5.86 & 1.66 & 14 & 4.05 & 2.19 & 16 & 1.81 & 0.72 & 28 & $2.52^{*}$ \\
\hline & $\begin{array}{l}\text { How long have you been working for this } \\
\text { company? } \\
1 \text { (<3 years) ... } 5 \text { (=15 years) }\end{array}$ & 4.36 & 0.84 & 14 & 4.06 & 0.85 & 16 & 0.29 & 0.31 & 28 & 0.95 \\
\hline & $\begin{array}{l}\text { The change into my current position has } \\
\text { been easy for me. } \\
1 \text { (totally disagree) ... } 7 \text { (totally agree) }\end{array}$ & 5.00 & 1.53 & 18 & 4.94 & 1.82 & 17 & 0.06 & 0.57 & 33 & 0.10 \\
\hline
\end{tabular}

Note. 2-tailed t-test; $* * * p=.001 * * p=.01 * p=.05$

\section{Measures}

All measures are self-assessments collected with the help of a questionnaire, which comprised items from various sources and for all the constructs in the model. Table 2 provides an overview of the constructs and their operationalisation.

All of the variables examined in this study had good internal consistencies, except for "acceptance by subordinates" (Cronbach's a $=.27$ ). The ratings on the three questionnaire items ${ }^{4}$ that dealt with this variable were very heterogeneous, which may indicate the ambivalence of the first-line manager's position. Clearly, more consistent measures should be developed for this variable. For now, the aggregate across the three items appears to be a conservative estimate of the actual feeling of being accepted as a manager by subordinates.

\footnotetext{
4 "For my subordinates, I'm rather one of them than their boss" (reverse-scored). "My subordinates sometimes directly turn to my superior instead of talking to me first" (reverse-scored). "I feel accepted by my subordinates as their manager."
} 
Table 2: Variables in the Model and their Operationalisation, Descriptive Statistics, and Correlations of Role Identity and the Outcome Variables

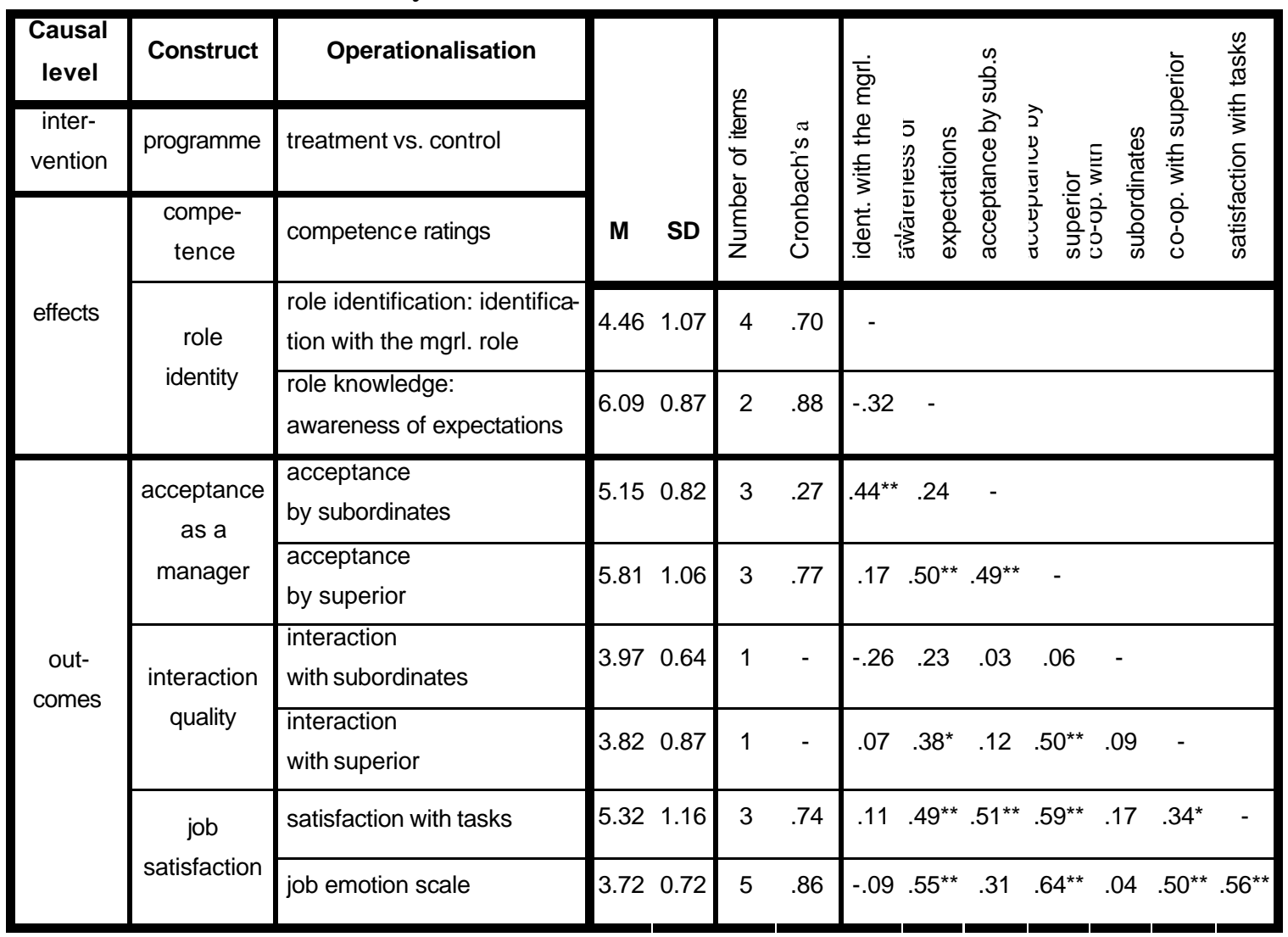

Note. $\mathrm{n}=38 ; * * * \mathrm{p}=.001 * * \mathrm{p}=.01 * \mathrm{p}=.05$

\section{Level 1: Intervention}

The intervention variable codes participation versus non-participation in the leadership development programme. All managers in the treatment group participated in the three parts of the programme. The three parts are, therefore, treated as one intervention.

\section{Level 2: Effect Variables}

The effect variables are those variables the training programme was supposed to directly affect. At the centre of these variables were the ratings of leadership competence. As none of the existing competency models fit the production unit managers' job exactly, a customized model was developed, which employed relevant competencies from models and analyses in the literature (Bittel \& Ramsey, 1983; Braun, 1979; Daniel, 1992; Dorando \& Grün, 1993; Gechter, 2002; Guthrie \& Schwoerer, 1996; Klagge, 1998; McEnery \& McEnery, 1987; Nethero, 1983; Pietruschka, 2003; Sandwith, 1993; Sheldrake \& Saul, 1995; 
Shipper \& White, 1999; Yukl et al., 1990) plus documentation from the host organisation (e.g., employee survey and training objectives). It comprised 35 competencies that, for a better overview, were classified into seven theory-based dimensions of leadership (see Table 3 ).

The exact wording of the competence measure was "Here is a list of tasks, which may be more or less relevant for your job. Please indicate how difficult it is for you to perform these activities at your workplace, no matter why it is difficult." The answer categories were "never difficult" (1), "rarely difficult" (2), "sometimes difficult" (3), "frequently difficult" (4), and "mostly difficult" (5). The raw data were inverted so that high numbers indicate a higher self-assessed competence.

In order to examine the validity of the model and to compare the subjective leadership theories of treatment and control group, the second section of the questionnaire had participants rate the importance of each competency ("please indicate how important you think each of these tasks is for your current job position") on a 5-point Likert-type scale ranging from "unimportant" (1) to "important" (5).

Competence and importance ratings were separated into two sequential sections because the latter might influence the accuracy of the self-assessments: If someone judges a task to be essential for their job, it might make them feel uncomfortable to admit that they are not good at that task.

In addition to competencies, the production unit managers' role identity was investigated in this study. Therefore, identification with the managerial role (e.g., "If I had to describe my professional function to someone else, I'd describe myself as a manager." [4 items]) and awareness of expectations (e.g., "I know exactly what is expected of me in this position." [2 items]) were measured using a 7-point Likert-type agreement scale ("totally disagree" (1) to "totally agree" (7)). 


\section{Level 3: Outcome Variables}

The following variables represent the outcomes that were supposed to be affected by the level of leadership competence and identity and ultimately by the training programme: acceptance as a manager, quality of the interaction with subordinates and superiors, and job satisfaction.

Acceptance as a manager by subordinates and superiors was measured by three items each (e.g., "For my subordinates, I'm rather one of them than their boss." "I feel accepted as a manager by my superior."). This variable was investigated using a 7-point Likert-type agreement scale ("totally disagree" (1) to "totally agree" (7)).

Quality of the interaction with subordinates and superiors was assessed using one straightforward question concerning subordinates and one straightforward question concerning superiors ("All in all, how satisfied are you with the interaction with your subordinates/superior?" [see Trost, Jöns, \& Bungard, 1999]). The items featured a 5-point Likert-type scale, ranging from "very dissatisfied" (1) to "very satisfied" (5).

Overall job satisfaction was measured, on the one hand, using a set of three items concerning satisfaction with one's tasks (e.g., "Sometimes I'd rather stand at one of the machines instead of sitting at the desk."). These items were based on comments by Vettermann and Dorando (2003) as well as the company's description of symptoms of dissatisfaction. This variable was examined using a 7-point Likert-type agreement scale. A second measure investigated the emotional experience of the job. It contained five items that specifically referred to emotions experienced in the course of the last working week (e.g., "To what extent over the last week did you feel satisfied?" [see Martin \& Wall, 1989]). A factor analysis confirmed that both positive emotions (satisfaction, interest) and negative emotions (frustration, stress, tension) constitute one dimension. ${ }^{5}$ The

\footnotetext{
${ }^{5}$ Only one factor has an Eigenvalue $>1$, and this factor explains 64 percent of the variance. The sixth item suggested by Martin and Wall (1989), challenge, was omitted because it constituted a separate dimension.
} 
emotional experience of managers was investigated using a 5-point Likert-type scale, ranging from "virtually never" (1) to "virtually always" (5).

\section{Results}

\section{Validation of the Competency Model}

Except for two items ("getting through one's opinion" $[M=3.42]$ and "regularly exchanging information with colleagues from other areas" $[M=$ 3.92]), the results of this study show that most of the competencies in the model were considered important to very important by employees (all means $>4$ [see Table 3]). Thus, the results confirm the appropriateness of the competencies investigated in this study.

The study participants also indicated that they have difficulties with areas they consider important (e.g., conflict resolution, motivation, feedback). The virtually non-existent correlation between assessments of competence and importance $(r=$ .07 , n.s.) confirms that the assessments were not influenced by personal strengths, weaknesses, or preferences; the managers were able to differentiate between importance and competence. Therefore, the results of this study appear to be an accurate description of the managers' view of their leadership roles.

\section{Analysis of the Managers' Situation}

Comparing traditional competencies (categories 6 and 7) with leadershiprelated competencies (categories 1 to 5$)^{6}$, a t-test for paired samples reveals a highly significant difference: The recently added tasks are clearly more difficult for production unit managers ${ }^{7}$, and this finding confirms $\mathrm{H} 1$.

Interestingly, the results show that both skilled workers and master craftsmen experienced more difficulties with leadership competencies than with traditional

\footnotetext{
${ }^{6}$ Statistical indicators of internal consistency support this aggregation (traditional: $\mathrm{a}=$ $.761,8$ items, $n=37$; leadership: a $=.910,27$ items, $n=33$ ), but comparable values would be found for any subset of highly intercorrelated variables.

${ }^{7}$ A 1-tailed t-test for paired samples shows that average competence in categories 1-5 differs significantly from average competence in categories 6-7 $(t=7.39 * * *)$.
} 
competencies. ${ }^{8}$ The master craftsmen also did not differ significantly from skilled workers in their overall level of competence $(t=0.28$, n.s. $)$. Obviously, the additional management training received during the master craftsman courses did not prepare them for the specific challenges of being production unit managers.

When the seven categories are arranged according to the average perception of difficulty, a clear ranking becomes apparent: Dealing with difficult subordinates is the most difficult task, followed by giving feedback, communication, delegation, relationship with subordinates, doing one's own job, and technical support. Paired ttests show that the steps from one category to the next are significant, except for those between communication/delegation and relationship with subordinates/doing one's own job (see Table 4). Therefore, the ranking also suggests that the managers have fewer difficulties with their more traditional tasks (categories 6 and 7) and that it is relatively difficult for them to fulfil their leadership role (categories 1 to 5).

\footnotetext{
${ }^{8}$ The $\mathrm{t}$-value for skilled workers is -4.71 , for master craftsmen -4.04 .
} 
Table 3: Competency model for production unit managers, with importance ratings by job incumbents

\begin{tabular}{|c|c|c|c|c|}
\hline Cat. & Competency & M & SD & $\mathbf{n}$ \\
\hline \multirow{6}{*}{ 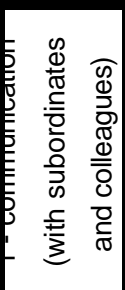 } & to convey information to my subordinates (e.g. by means of a short presentation) & 4.55 & 0.69 & 38 \\
\hline & to effectively conduct group meetings & 4.53 & 0.65 & 38 \\
\hline & to make clear agreements with individual subordinates & 4.87 & 0.34 & 38 \\
\hline & to get through my opinion & 3.42 & 0.76 & 38 \\
\hline & to regularly exchange information with colleagues from other areas & 3.92 & 0.88 & 38 \\
\hline & to show the right level of interest in my subordinates & 4.53 & 0.56 & 38 \\
\hline \multirow{4}{*}{ 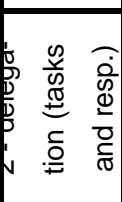 } & to delegate tasks to my subordinates & 4.29 & 0.61 & $\overline{38}$ \\
\hline & to negotiate objectives together with my subordinates & 4.42 & 0.76 & 38 \\
\hline & to give responsibility to my subordinates & 4.34 & 0.78 & 38 \\
\hline & to rely on subordinates' doing a job well & 4.74 & 0.50 & 38 \\
\hline \multirow{7}{*}{ 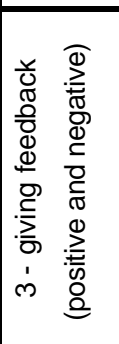 } & to give feedback on goal attainment & 4.51 & 0.69 & 37 \\
\hline & to evaluate performance/behavior openly and fairly & 4.66 & 0.48 & 38 \\
\hline & to recognize and commend good performance & 4.63 & 0.54 & 38 \\
\hline & to talk with subordinates about poor performance & 4.71 & 0.46 & 38 \\
\hline & to give negative feedback to subordinates without putting a strain on the relationship & 4.45 & 0.65 & 38 \\
\hline & to conduct an effective performance appraisal & 4.37 & 0.85 & 38 \\
\hline & to talk to an employee who has repeatedly made the same mistake & 4.74 & 0.60 & 38 \\
\hline \multirow{5}{*}{ 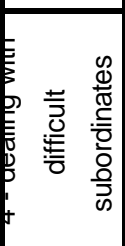 } & to spot conflicts early on & 4.66 & 0.63 & 38 \\
\hline & to resolve conflicts with subordinates & 4.76 & 0.49 & 38 \\
\hline & to resolve conflicts with colleagues & 4.50 & 0.80 & 38 \\
\hline & to deal with difficult subordinates & 4.45 & 0.69 & 38 \\
\hline & to motivate my subordinates & 4.76 & 0.43 & 38 \\
\hline \multirow{5}{*}{ 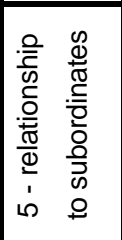 } & to regularly be in touch with my subordinates & 4.63 & 0.71 & 38 \\
\hline & to accept my subordinates as partners & 4.26 & 0.95 & 38 \\
\hline & to shield my subordinates against difficulties/criticism & 4.68 & 0.53 & 38 \\
\hline & to represent the interests of my area towards my superior & 4.71 & 0.52 & 38 \\
\hline & to represent the interests of my area towards my colleagues & 4.37 & 0.91 & 38 \\
\hline \multirow{3}{*}{ 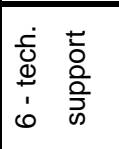 } & to support my subordinates in technical problems & 4.79 & 0.41 & 38 \\
\hline & to be quickly available in case of problems and questions & 4.68 & 0.47 & 38 \\
\hline & to impart technical knowledge & 4.45 & 0.69 & 38 \\
\hline \multirow{5}{*}{ 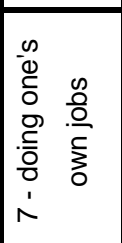 } & to make fast and clear decisions & 4.82 & 0.39 & 38 \\
\hline & to admit mistakes & 4.61 & 0.55 & 38 \\
\hline & to analyze a problem and find the best solution & 4.63 & 0.49 & 38 \\
\hline & to effectively manage my own time & 4.55 & 0.69 & 38 \\
\hline & to be an example (e.g. in terms of reliability, credibility, honesty, etc.) & 4.89 & 0.31 & 38 \\
\hline
\end{tabular}

Note. Scale 1 (unimportant) ... 5 (important). 
Table 4: Competency categories in order of average level of competence

\begin{tabular}{|c|c|c|c|c|c|c|c|c|}
\hline \multicolumn{2}{|r|}{ Competency Category } & \multicolumn{3}{|c|}{ Aggregate } & \multicolumn{4}{|c|}{$\begin{array}{l}\text { Difference between } \\
\text { Categories }\end{array}$} \\
\hline & & M & SD & $\mathbf{n}$ & M & SD & df & $\mathbf{t}$ \\
\hline \multirow[t]{2}{*}{4} & \multirow{2}{*}{$\begin{array}{l}\text { dealing with difficult subordinates } \\
\text { (e.g. motivation, conflicts) }\end{array}$} & \multirow[t]{2}{*}{3.28} & \multirow[t]{2}{*}{.57} & \multirow[t]{2}{*}{37} & & & & \\
\hline & & & & & .43 & .55 & 33 & $4.56^{\star \star \star}$ \\
\hline \multirow[t]{2}{*}{3} & \multirow[t]{2}{*}{ giving feedback (positive and negative) } & \multirow[t]{2}{*}{3.69} & \multirow[t]{2}{*}{.62} & \multirow[t]{2}{*}{38} & & & & \\
\hline & & & & & .20 & .51 & 34 & $2.35^{\star}$ \\
\hline \multirow[t]{2}{*}{2} & \multirow[t]{2}{*}{ delegation (of tasks and responsibilities) } & \multirow[t]{2}{*}{3.86} & \multirow[t]{2}{*}{.63} & \multirow[t]{2}{*}{38} & & & & \\
\hline & & & & & .03 & .54 & 34 & 0.36 \\
\hline \multirow[t]{2}{*}{1} & communication & \multirow[t]{2}{*}{3.86} & \multirow[t]{2}{*}{.52} & \multirow[t]{2}{*}{38} & & & & \\
\hline & (with subordinates and colleagues) & & & & .17 & .45 & 33 & $2.22^{*}$ \\
\hline \multirow[t]{2}{*}{5} & relationship to subordinates & \multirow[t]{2}{*}{4.03} & \multirow[t]{2}{*}{.56} & \multirow[t]{2}{*}{37} & & & & \\
\hline & & & & & .04 & .44 & 33 & 0.46 \\
\hline \multirow[t]{2}{*}{7} & doing one's own jobs & \multirow[t]{2}{*}{4.06} & \multirow[t]{2}{*}{.47} & \multirow[t]{2}{*}{37} & & & & \\
\hline & (e.g. making decisions, time management) & & & & \multirow[t]{2}{*}{.28} & \multirow[t]{2}{*}{.52} & \multirow[t]{2}{*}{33} & \multirow[t]{2}{*}{$3.05^{\star \star}$} \\
\hline 6 & technical support of subordinates & 4.30 & .57 & 37 & & & & \\
\hline
\end{tabular}

Note. 1-tailed t-test for paired samples; $* * * p=.001 * * p=.01 * p=.05$.

\section{Should Leadership Competencies and Identity Be Promoted?}

For the ensuing tests of the effects of leadership competence, two alternative indicators of the overall level of competence were used. First, the unweighted mean across the 35 competencies was computed for each production unit manager. Second, in order to better reflect the varying importance of the competencies, equation (1) was used to compute a weighted aggregate of the competencies. ${ }^{9}$ In this study, the difference between the weighted and the unweighted mean level of competence is very small $\left(r=.86^{* * *}\right)$. This is due to the fact that most competencies were seen as homogeneously important by the production unit managers.

In order to test hypothesis 3 , the outcome variables were regressed on the aggregate level of competence. Results from an ordinary least squares regression analysis ${ }^{10}$ with the weighted and unweighted aggregate indicate that more

\footnotetext{
${ }^{9}$ The weighted competence aggregates computed by multiplying the values with their weights and dividing the sum of these products by the sum of the weights correlate at $r$ $=1.00 * * *$ with the unweighted scores. As the results are practically identical with those of the unweighted aggregate, they are not reported here.

${ }^{10}$ Ordered Probit regression leads to equivalent results, which confirms their robustness towards distributional assumptions.
} 
competent production unit managers are better accepted in their role as managers by their superiors but not by their subordinates. Therefore, the results support $\mathrm{H} 3 \mathrm{~b}$ but not H3a. Comparing coefficients of the weighted and unweighted aggregates of the competencies, it was found that both acceptance by and interaction with superiors are easier to predict when the managers' importance weights are not included. This finding suggests that the managers' superiors have a different view of the production unit manager job, and their acceptance and cooperation depend on competencies other than those judged important by the managers themselves. Conversely, it was only possible to significantly predict the quality of the interaction with subordinates using the weighted competence aggregate. It appears that the managers have valid ideas about the competencies that are important for smooth interaction with subordinates. Thus, the findings for interaction quality partly support $\mathrm{H} 3 \mathrm{c}$ and fully support $\mathrm{H} 3 \mathrm{~d}$. The level of competence was closely associated with job satisfaction: More competent managers were more satisfied with their jobs and experience more positive and less negative emotions on the job. This finding supports hypothesis $\mathrm{H} 3 \mathrm{e}$. The influences of competence on acceptance as a manager, quality of the interaction, and job satisfaction are shown in Table 5. 
Table 5: Regression of Outcome Variables on Level of Competence and Role Identity

\begin{tabular}{|c|c|c|c|c|c|}
\hline \multirow{2}{*}{\multicolumn{2}{|c|}{ Item }} & \multicolumn{2}{|c|}{ Competence } & \multicolumn{2}{|c|}{ Role Identity } \\
\hline & & weighted & unweighted & identification with & awareness of \\
\hline \multirow{2}{*}{ 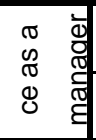 } & acceptance by subordinates & .01 & .07 & $.19^{\star *}$ & .06 \\
\hline & acceptance by superior & $.11^{*}$ & $.22^{\star \star}$ & .03 & $.25^{\star \star}$ \\
\hline \multirow{2}{*}{ 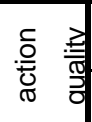 } & interaction with subordinates & $.18^{\star *}$ & .10 & .07 & .05 \\
\hline & interaction with superior & $.12^{*}$ & $.19^{\star *}$ & .00 & $.15^{\star}$ \\
\hline \multirow{2}{*}{ 离 } & satisfaction with tasks & $.12^{*}$ & $.15^{\star}$ & .01 & $.24^{\star \star}$ \\
\hline & job emotion scale & $.18^{\star \star}$ & $.21^{\star *}$ & .01 & $.30^{\star \star \star}$ \\
\hline
\end{tabular}

Note. Determination coefficients based on negative regression coefficients are set in italics; $n=38$; *** $p$ $=.001 * p=.01 * p=.05$.

The findings show that supervisors who see themselves as managers are better accepted in their role as managers by their subordinates but not by their superiors (see Table 5). While awareness of expectations did not predict acceptance from subordinates, it did predict acceptance from superiors and also the quality of the interaction with superiors. Being aware of the expectations associated with the unit and the manager position also appeared to be an important prerequisite for job satisfaction. This observation holds for both measures. However, identification with the managerial role did not increase job satisfaction. Therefore, the findings support H4a, H5b, H5d, and H5e, but they do not support $\mathrm{H} 4 \mathrm{~b}$ to $\mathrm{H} 4 \mathrm{e}, \mathrm{H} 5 \mathrm{a}$, and $\mathrm{H} 5 \mathrm{c}$.

\section{Can Leadership Competencies and Identity Be Promoted?}

The weighting makes a considerable difference in the results when examining whether participation in management training and coaching has a positive impact on the overall level of competence. The groups differed significantly on the unweighted aggregate, but they did not differ on the weighted aggregate (see Table 6). This finding illustrates that the strongest differences occurred for variables that were not considered important by these first-line managers. Therefore, the findings partially support $\mathrm{H} 2$. 
Table 6: Differences between Participants and Non-Participants of Training and Coaching on Effect Measures

\begin{tabular}{|c|c|c|c|c|c|c|c|c|c|c|c|c|}
\hline \multicolumn{2}{|r|}{ Item } & \multicolumn{3}{|c|}{ Treatment } & \multicolumn{3}{|c|}{ Control } & \multicolumn{5}{|c|}{ Difference } \\
\hline & & M & SD & & M & SD & n & M & S & & & $t$ \\
\hline \multirow{2}{*}{ 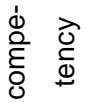 } & weighted aggregate & 3.89 & 0.46 & & 3.87 & 0.66 & 17 & 0.0 & 0.1 & & & 0.14 \\
\hline & unweighted aggregate & 3.97 & 0.37 & 18 & 3.69 & 0.48 & 17 & 0.2 & 0.1 & & & $1.93^{*}$ \\
\hline \multirow{2}{*}{ 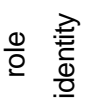 } & identification with the managerial role & 4.43 & 1.22 & 18 & 4.35 & 0.93 & 17 & 0.0 & 0.3 & & 3 & 0.21 \\
\hline & awareness of expectations & 6.33 & 0.95 & 18 & 5.94 & 0.77 & 17 & 0.3 & 0.2 & & 3 & 1.33 \\
\hline
\end{tabular}

Note. Competence scale (reverse-scored): 1 (mostly difficult) .. 5 (never difficult); role identity scale: 1 (totally disagree) ... 7 (fully agree); 1-tailed t-test; $* * * p=.001 * * p=.01 * p=.05$.

Doing a post-hoc analysis of the effects of the leadership development programme on specific competencies, it was found that on all competencies the programme participants felt at least as competent as the production unit managers who had not yet participated in the programme. On 9 items, managers who participated in the development programme felt significantly ${ }^{11}$ more competent. The findings show that the development programme improved managers' communication and conflict resolution with colleagues from other production units, ${ }^{12}$ improved their ability to be role models, ${ }^{13}$ and promoted a more partneroriented management style. ${ }^{14}$ All of these competencies point to an increased self-confidence of the managers who took part in the programme (see Table 7).

\footnotetext{
${ }_{11}$ Again, 1-tailed t-tests for independent groups are used.

12 This cluster of significant results comprises four items: (1) to regularly exchange information with colleagues from other areas, (2) to resolve conflicts with colleagues, (3) to represent the interests of my subordinates towards my colleagues, and (4) to get through my opinion.

${ }^{13}$ This cluster of significant results comprises two items: (1) to be an example in terms of reliability, credibility, honesty, and (2) to admit mistakes.

${ }^{14}$ This cluster of significant results comprises three items: (1) to accept my subordinates as partners, (2) to give responsibility to my subordinates, and (3) to rely on subordinates' doing a job well.
} 
Table 7: Differences between participants and non-participants of training and coaching in the assessment of competence on the leadership competencies

\begin{tabular}{|c|c|c|c|c|c|c|c|c|c|c|c|}
\hline$\frac{\bar{\Phi}}{\frac{\Phi}{5}}$ & Competency & & atme & & & Oontro & & & Diffe & rence & \\
\hline 0 & & $\mathbf{M}$ & SD & $\mathbf{n}$ & M & SD & $\mathbf{n}$ & M & SE & df & $t$ \\
\hline 3 & to accept my subordinates as partners & 4.59 & 0.62 & 17 & 3.82 & 0.81 & 17 & 0.76 & 0.25 & 32 & $3.10^{* *}$ \\
\hline 1 & $\begin{array}{l}\text { to regularly exchange information with } \\
\text { colleagues from other areas }\end{array}$ & 4.39 & 0.92 & 18 & 3.65 & 0.86 & 17 & 0.74 & 0.30 & 33 & $2.46^{* *}$ \\
\hline 1 & to resolve conflicts with colleagues & 4.25 & 0.58 & 16 & 3.59 & 0.80 & 17 & 0.66 & 0.24 & 31 & $2.72^{* *}$ \\
\hline 1 & $\begin{array}{l}\text { to represent the interests of my area towards } \\
\text { my colleagues }\end{array}$ & 4.35 & 0.61 & 17 & 3.71 & 0.59 & 17 & 0.65 & 0.20 & 32 & $3.16^{* *}$ \\
\hline 1 & to get through my opinion & 3.94 & 0.43 & 17 & 3.35 & 0.61 & 17 & 0.59 & 0.18 & 32 & $3.27^{\star *}$ \\
\hline 3 & to rely on subordinates' doing a job well & 3.89 & 0.90 & 18 & 3.35 & 0.86 & 17 & 0.54 & 0.30 & 33 & $1.80^{*}$ \\
\hline 2 & $\begin{array}{l}\text { to be an example (e.g. in terms of reliability, } \\
\text { credibility, honesty, etc.) }\end{array}$ & 4.65 & 0.49 & 17 & 4.12 & 0.60 & 17 & 0.53 & 0.19 & 32 & $2.81^{* *}$ \\
\hline 3 & to give responsibility to my subordinates & 4.06 & 0.80 & 18 & 3.53 & 0.94 & 17 & 0.53 & 0.30 & 33 & $1.78^{*}$ \\
\hline & to conduct an effective performance appraisal & 3.78 & 0.94 & 18 & 3.29 & 0.92 & 17 & 0.48 & 0.32 & 33 & 1.54 \\
\hline 2 & to admit mistakes & 4.47 & 0.72 & 17 & 4.00 & 0.71 & 17 & 0.47 & 0.24 & 32 & $1.93^{*}$ \\
\hline & to regularly be in touch with my subordinates & 4.24 & 0.75 & 17 & 3.82 & 0.88 & 17 & 0.41 & 0.28 & 32 & 1.46 \\
\hline & $\begin{array}{l}\text { to talk to an employee who has repeatedly } \\
\text { made the same mistake }\end{array}$ & 4.17 & 0.79 & 18 & 3.76 & 0.90 & 17 & 0.40 & 0.29 & 33 & 1.41 \\
\hline & $\begin{array}{l}\text { to talk with subordinates about poor } \\
\text { performance }\end{array}$ & 3.78 & 1.06 & 18 & 3.41 & 0.87 & 17 & 0.37 & 0.33 & 33 & 1.11 \\
\hline & to make fast and clear decisions & 4.35 & 0.61 & 17 & 4.00 & 0.71 & 17 & 0.35 & 0.23 & 32 & 1.56 \\
\hline & $\begin{array}{l}\text { to give negative feedback to subordinates } \\
\text { without putting a strain on the relationship }\end{array}$ & 3.33 & 0.97 & 18 & 3.00 & 0.87 & 17 & 0.33 & 0.31 & 33 & 1.07 \\
\hline & $\begin{array}{l}\text { to shield my subordinates against } \\
\text { difficulties/criticism }\end{array}$ & 4.35 & 0.70 & 17 & 4.06 & 0.66 & 17 & 0.29 & 0.23 & 32 & 1.26 \\
\hline & to effectively conduct group meetings & 3.72 & 0.57 & 18 & 3.47 & 1.12 & 17 & 0.25 & 0.30 & 33 & 0.84 \\
\hline & $\begin{array}{l}\text { to negotiate objectives together with my } \\
\text { subordinates }\end{array}$ & 4.00 & 0.59 & 18 & 3.76 & 0.66 & 17 & 0.24 & 0.21 & 33 & 1.11 \\
\hline & $\begin{array}{l}\text { to support my subordinates in technical } \\
\text { problems }\end{array}$ & 4.71 & 0.59 & 17 & 4.47 & 0.80 & 17 & 0.24 & 0.24 & 32 & 0.98 \\
\hline & $\begin{array}{l}\text { to be quickly available in case of problems and } \\
\text { questions }\end{array}$ & 4.18 & 0.81 & 17 & 3.94 & 0.75 & 17 & 0.24 & 0.27 & 32 & 0.88 \\
\hline & $\begin{array}{l}\text { to convey information to my subordinates (e.g. } \\
\text { by means of a short presentation) }\end{array}$ & 4.17 & 0.99 & 18 & 3.94 & 0.75 & 17 & 0.23 & 0.30 & 33 & 0.76 \\
\hline & to delegate tasks to my subordinates & 4.33 & 0.84 & 18 & 4.12 & 0.70 & 17 & 0.22 & 0.26 & 33 & 0.82 \\
\hline & $\begin{array}{l}\text { to evaluate performance/behavior openly and } \\
\text { fairly }\end{array}$ & 3.78 & 1.00 & 18 & 3.59 & 0.80 & 17 & 0.19 & 0.31 & 33 & 0.62 \\
\hline & to deal with difficult subordinates & 2.94 & 1.03 & 17 & 2.76 & 0.97 & 17 & 0.18 & 0.34 & 32 & 0.51 \\
\hline & to effectively manage my own time & 3.53 & 0.87 & 17 & 3.35 & 0.93 & 17 & 0.18 & 0.31 & 32 & 0.57 \\
\hline & to give feedback on goal attainment & 3.78 & 0.81 & 18 & 3.65 & 1.17 & 17 & 0.13 & 0.34 & 33 & 0.39 \\
\hline & to impart technical knowledge & 4.41 & 0.71 & 17 & 4.29 & 0.59 & 17 & 0.12 & 0.22 & 32 & 0.53 \\
\hline & to analyze a problem and find the best solution & 4.12 & 0.70 & 17 & 4.00 & 0.79 & 17 & 0.12 & 0.26 & 32 & 0.46 \\
\hline & to recognize and commend good performance & 4.11 & 1.02 & 18 & 4.06 & 0.85 & 16 & 0.05 & 0.33 & 32 & 0.15 \\
\hline & $\begin{array}{l}\text { to show the right level of interest in my } \\
\text { subordinates }\end{array}$ & 3.72 & 0.96 & 18 & 3.69 & 0.95 & 16 & 0.03 & 0.33 & 32 & 0.11 \\
\hline & $\begin{array}{l}\text { to represent the interests of my area towards } \\
\text { my superior }\end{array}$ & 3.65 & 1.17 & 17 & 3.65 & 0.93 & 17 & 0.00 & 0.36 & 32 & 0.00 \\
\hline & $\begin{array}{l}\text { to make clear agreements with individual } \\
\text { subordinates }\end{array}$ & 4.06 & 0.87 & 18 & 4.06 & 0.66 & 17 & 0.00 & 0.26 & 33 & -0.01 \\
\hline & to resolve conflicts with subordinates & 3.06 & 0.66 & 17 & 3.12 & 0.99 & 17 & -0.06 & 0.29 & 32 & -0.20 \\
\hline & to motivate my subordinates & 3.29 & 0.69 & 17 & 3.41 & 0.94 & 17 & -0.12 & 0.28 & 32 & -0.42 \\
\hline & to spot conflicts early on & 3.00 & 0.50 & 17 & 3.18 & 0.88 & 17 & -0.18 & 0.25 & 32 & -0.72 \\
\hline
\end{tabular}

Note. Ranked in order of difference; reverse-scored scale 1 (mostly difficult) ... 5 (never difficult); $1-$ tailed t-test; $* * * p=.001 * * p=.01 * p=.05$. 
As most of the competencies in the model were unanimously considered important by the managers (see Table 3), there was not much difference between participants and non-participants of the development programme. Nonetheless, one competency was considered significantly less important by programme participants: They felt it was less important to enforce their opinion $\left(t=-2.61^{*}\right)$. This again suggests that the managers view their subordinates as partners.

The effects of leadership development training on role identity were, in general, weaker than those for competencies, and participants of the development programme did not differ significantly from non-participants, either in terms of identification with the managerial role or in terms of the awareness of expectations (see Table 6). These findings do not support $\mathrm{H} 2 \mathrm{c}$ and $\mathrm{H} 2 \mathrm{~d}$. However, two significant differences on single items are noteworthy. With regard to identification with the management role, the ratings of the item "If I had to describe my professional function to someone else, I'd describe myself as a manager" indicate that the programme participants had a clearer identity as a manager than their colleagues who had not participated in the programme $(t=$ $\left.1.87^{*}\right)$. Nonetheless, it is remarkable that they would make less use of the power of their position to enforce their will $\left(t=-1.70^{*}\right)$.

\section{Discussion}

\section{Contributions}

The present study revealed some noteworthy relationships involving production unit managers' leadership competencies and identity after the introduction of autonomous production teams. It shows that leadership-related tasks posed the most prevalent problems for the supervisors: dealing with difficult subordinates was the most difficult task, followed by giving feedback, communication, delegation, and relationships with subordinates. The traditional tasks of doing one's own job and giving technical support to others were more competently mastered. Therefore, production unit managers' interpersonal and leadership skills should receive more attention in practice and research. 
The results of this study indicate that acceptance as a manager by subordinates does not depend on the level of competence. This is in contrast to research conducted with higher-level managers, whose acceptance by subordinates primarily depends on their competence as perceived by subordinates (Javidan, 1995). Future research should investigate what other factors might facilitate the acceptance of the first-line managers' new role. Superiors, though, accept competent managers significantly better and delegate more tasks and responsibilities, especially to those who are assertive when it comes to defending their unit and who actively communicate with colleagues and subordinates. Next, the quality of the interaction with subordinates and superiors is judged more positively with increasing competence, particularly in the realm of attitudes towards subordinates. Finally, the results of this study show that when there is a match between demands and competencies first-line managers experience significantly greater job satisfaction. In particular, competencies that involve relationships with subordinates and the ability to motivate are strongly correlated with job satisfaction.

Managers who have a strong identification with the managerial role (i.e., those who see themselves as a manager) are also better accepted as a manager by their subordinates. The awareness of the superiors' expectations is the best predictor of acceptance by superiors and also a strong predictor of job satisfaction. This finding has an implication for leadership development in practice: If upper level managers attended workshops for managers, they would be able to clarify their expectations to production unit managers.

Leadership training and coaching can increase leadership competencies. Nine out of 35 competencies were significantly higher for the treatment group. However, the significant differences were not found on those competencies judged most important by the study participants, so on the weighted mean, the groups were not different.

The greatest training effects involved behaviour towards colleagues. This finding is similar to the observations of Schmidt-Braße et al. (2001). These researchers found that communication with colleagues was one of the most 
evident improvements after a leadership training for foremen, both from the participants' and their superiors' perspective. Apparently, this is a competency new managers have to, and can, acquire in a development programme.

Further major training effects involve assertive behaviour and, interestingly, the acceptance of subordinates as partners. Several findings suggest that the managers' understanding of leadership is partner-oriented: The training participants described themselves more often as managers than the control participants. At the same time, they found it significantly easier to accept their subordinates as partners (largest difference treatment versus control), and they were less willing to use the power of their position to enforce their will. Moreover, they found it less important to enforce their opinion and more important to show the right level of interest in their subordinates (the only two significant differences in importance ratings). All these findings point to the managers' view of their subordinates as partners. At first glance, this looks like a paradox, but it possibly reflects the managers' understanding of their role: being a leader but working with their subordinates as partners.

Being a manager and a partner of subordinates does not seem to be a contradiction for first-line managers. On the contrary, for them, leadership seems to be associated with partnership. Possibly, this style is their solution to a wellknown problem of the recruitment of managers from the shop floor, namely, many managers maintain friendships with subordinates ${ }^{15}$ and find it difficult to take disciplinary action. Authority and friendship are hard to combine (Harrison, 1982), and it would seem that they cannot be combined through authoritative leadership. Future research might clarify the nature and strengths and weaknesses of the partner-oriented leadership style.

Rauen (1999) suggests three conditions that make for successful coaching. First, coaching should be voluntary. As supervisors would generally not consider asking for coaching sessions (compare the finding that very few production unit managers in this study attended coaching sessions on their own but preferred to

\footnotetext{
${ }^{15}$ On average, the production unit managers in the present sample were in touch with almost two subordinates outside work (see Table 1).
} 
participate in the sessions with a colleague), participation is usually prescribed at this level, as opposed to higher levels of management (Dorando \& Grün, 2004). Therefore, the company examined in this study chose a compromise solution by requiring the production unit managers to test the method while allowing them to discontinue the coaching component of the programme after the fifth session. The data show that most participants wanted to continue the coaching after the fifth session. Although this points to a general acceptance of the coaching method, some scepticism about involuntary involvement might have inhibited the process during the first few sessions, that is, coaching with voluntary participants might have yielded larger effects. Dorando and Grün (2004) conclude that prescribed coaching can be very successful if managers understand that the prescription is intended to help them and they are committed to the process.

Second, confidentiality has to be guaranteed. Therefore, only external coaches should be used. In this study, an internal coach ran the sessions and explicitly promised confidentiality. The results suggest that some participants did not fully trust the setting. This is a critical issue for companies because effectiveness was shown in this study to depend on confidentiality.

Third, personal acceptance of the coach by the manager is a basic condition for a successful working relationship. Rauen's (1999) suggestion is supported by the present data: The effectiveness of coaching depends on personal acceptance of the coach by the manager. It is recommended, therefore, even in prescribed coaching, that the manager choose his or her coach (Dorando \& Grün, 2004). In this study, only one coach was available, so the participants had no opportunity to choose a coach. Thus, in the case of personality conflicts, managers may have resigned themselves to attending the coaching sessions. This could have resulted in dissatisfactory coaching effects that could have been avoided if managers had the chance to choose their own coach.

In this study, the three basic conditions for successful coaching were not ideally met. Future studies should investigate manager development programmes that include coaching that more closely meets the conditions for successful coaching. In general, more empirical research that investigates coaching is 
needed, particularly in view of the increasing use of coaching in organisations. By 2000, not a single study existed that examined the effects of coaching under controlled conditions (Stahl \& Marlinghaus, 2000). The present study has shed some light on the benefits of coaching, and it empirically supports the effectiveness of coaching.

This research could not clarify the interrelations of the competencies in the model. The internal consistency of the hypothesized dimensions was very low, and factor analysis did not yield a systematic structure. Additional research should identify the higher-level constructs on the basis of which the production unit managers' competencies can be grouped meaningfully.

A new scale format for the measurement of competencies through selfassessments has been suggested. The results of its use in the present study are of methodological interest. The scale yielded considerably more variance than is usually found in self-ratings obtained with other scales (e.g., Daniel, 1992). For a meaningful statistical test, the same constructs would have to be measured in the same population with alternative scales, an issue that is worth pursuing.

The suggested format attempted to correct three major sources of bias: unclear constructs, inappropriate rating scales, and motivation for self-enhancement. Evidently, it cannot correct the fourth problem, which is inherent in the nature of self-assessments, namely, inaccurate self-images. Here, two factors have to be weighted against each other: (1) what the individual does not know about him- or herself and (2) what the individual does know about him- or herself, perhaps better than anyone else. The famous Johari window illustrates that no source can ever paint a complete picture (Hossiep \& Paschen, 1998). In the present sample, sufficient self-knowledge was assumed based on reports of the coach that the production unit managers were well aware of the difficulties they had with certain tasks.

\section{Limitations}

The results of this study did not demonstrate causality. Additional work must be done to confirm the postulated causal relationships. 
First, the impact of training on leadership competence and identity is at issue. As in all quasi-experiments, threats to internal validity need to be taken seriously. Due to the use of non-randomized groups, it is possible that pre-existing differences constitute an alternative explanation for the training effects and outcomes found in this study. Although the tests conducted support the assumption of equivalence of the groups, the samples might have differed on other variables that were not measured.

Second, the impact of leadership competence and identity on outcome variables also requires consideration. One alternative explanation for the associations found in this study could be a common cause. Although the assumed relationships seemed plausible, this cannot be excluded, particularly because the source of all measurements was the participant. Therefore, their relationships could be inflated (see, for example, Yukl et al., 1990). However, the relationships between the effect level and the outcome level were low and in some cases (insignificantly) negative. Therefore, the participants seem to have assessed both levels independently, with little halo shining from one level to the other.

In order to assess the generalisability to other organisations and demonstrate external validity, the findings need to be replicated in different settings, particularly in organisations with different structures, processes, climates, training programmes, managers, and outcome measures.

There are three aspects of the present study that could have reduced the statistical conclusion validity.

First, the tests conducted had little statistical power due to the small sample size. This may have led to the rejection of hypotheses that may have been confirmed with a larger sample. Second, if the assumptions of statistical tests are incorrect, the conclusions based on them may be invalid. In particular, the regression model presupposes a linear relationship among variables. However, if the relationship is of a different nature, it might be underestimated by the regression coefficients (Griliches \& Hausman, 1986). For instance, Boyatzis (1982) found a non-linear relationship between the competency of developing 
others (giving subordinates feedback on their job performance, helping individual workers with job-related problems, ability to counsel or advise subordinates about the job) and job performance: Average performers exhibited significantly more of this competency than poor or superior performers. Therefore, the present results might reflect the lower end of the true effects. Third, it could be said that this study was fishing for effects and that some significances are bound to emerge when so many statistical tests are computed. Here, it should be pointed out that, with one exception, all significant relationships are in the hypothesized direction.

\section{Conclusions}

The production unit managers perform an increasingly important role in the modern work organisation. Since the introduction of self-managed work groups, many managerial responsibilities have been transferred to this position. This study shows that production unit managers find these leadership-related tasks difficult, even after performing this job for several years, and that role identification and clarity are often moderate. Therefore, it is necessary to improve front-line managers' leadership competencies and identity because this increases their acceptance as a manager, the quality of the interaction with subordinates and superiors, and their job satisfaction. This study found that leadership training and coaching hardly affect role identity but can enhance the leadership competencies of former shop-floor workers.

\section{References}

Abramis, D. J. (1994). Work role ambiguity, job satisfaction, and job performance: Meta-analyses and review. Psychological Reports, 75(3), 1411-1433.

Appelbaum, E., Bailey, T., Berg, P., \& Kalleberg, A. L. (2000). Manufacturing advantage: Why high-performance work systems pay off. Ithaca, NY: Cornell University Press.

Ash, R. A. (1980). Self-assessments of five types of typing ability. Personnel Psychology, 33, 273-282. 
Bandura, A. (1978). The self system in reciprocal determinism. American Psychologist, 33, 344-358.

Barton, H., \& Delbridge, R. (2001). Development in the learning factory: Training human capital. Journal of European Industrial Training, 25(9), $465-472$.

Batt, R. (2001). The economics of teams among technicians. British Journal of Industrial Relations, 39(1), 1-25.

Batt, R. (2004). Who benefits from teams? Comparing workers, supervisors, and managers. Industrial Relations, 43, 183-212.

Bittel, L. R., \& Ramsey, J. E. (1983). New dimensions for supervisory training and development. Training \& Development Journal, 37(3), 12-20.

Boyatzis, R. E. (1982). The competent manager: A model for effective performance. New York: Wiley.

Braun, A. (1979). Assessing supervisory training needs and evaluating effectiveness. Training \& Development Journal, 33(2), 3-10.

Colvin, A., Batt, R., \& Katz, H. (2001). How high performance human resource practices and workforce unionization affect managerial pay. Personnel Psychology, 54, 903-934.

Cooper, C. L., Sloan, R. P., \& Williams, J. (1988). Occupational Stress Indicator. Windsor: NFER-NELSON.

Crumb, C. V. (1981). Performance-based line supervisor training. Training \& Development Journal, 35(9), 44-47.

Daniel, T. L. (1992). Identifying critical leadership competencies of manufacturing supervisors in a major electronics corporation. Group \& Organization Management, 17(1), 57-71.

del Gaizo, E. (1984). Proof that supervisory training works. Training \& Development Journal, 38(3), 30-31. 
DeNisi, A. S., \& Shaw, J. B. (1977). Investigation of the uses of self-predictions and judgements by others in psychological assessment. Journal of Applied Psychology, 62, 641-644.

Dorando, M., \& Grün, J. (1993). Coaching mit Meistern: Erfahrungsbericht eines supervisorischen Abenteuers [Coaching with foremen: Field report of a supervisory adventure]. Supervision, 24, 53-70.

Dorando, M., \& Grün, J. (2004). Verordnetes Coaching im betrieblichen Kontext [Prescribed coaching in the organisational context]. Personalführung, $37(1), 40-45$.

Finegold, D. L., \& Mason, G. (1999). National training systems and industrial performance: US-European matched-plant comparisons. Research in Labor Economics, 18, 331-358.

Finegold, D. L., \& Wagner, K (1999). The German skill-creation system and team-based production: Competitive asset or liability? In D. Culpepper \& D. L. Finegold (Eds.), The German skills machine: Sustaining comparative advantage in a global economy (pp. 115-158). New York: Berghahn Books.

Finger-Hamborg, A. (2002). Einzel-Coaching mit Schichtleitern: Ein Erfahrungsbericht [Individual coaching with shift leaders: A field report]. In C. Rauen (Ed.), Handbuch Coaching (pp. 227-249). Göttingen: Hogrefe.

Ford, J. K., \& Noe, R. A. (1987). Self-assessed training needs: The effects of attitudes toward training, managerial level, and function. Personnel Psychology, 40(1), 39-53.

Frisch, M. H. (2001). The emerging role of the internal coach. Consulting Psychology Journal: Practice \& Research, 53(4), 240-250.

Gechter, S. (2002). Verhaltensnahe Beurteilungssysteme [Behaviour-based appraisal systems]. Unternehmensberater, 8(3), 66-69.

Gilmour, P., \& Lansbury, R. (1986). The first line supervisor and their managerial role. Journal of Management Development, 5(3), 59-72. 
Griliches, Z., \& Hausman, J. (1986). Errors in variables in panel data. Journal of Econometrics, 31, 93-118.

Grimm, J. W., \& Dunn, T. P. (1986). The contemporary foreman status: Illustrative evidence from an automobile assembly plant. Work \& Occupations, 13(3), 359-376.

Guthrie, J. P., \& Schwoerer, C. E. (1996). Older dogs and new tricks: Career stage and self-assessed need for training. Public Personnel Management, 25(1), 59-72.

Hall, M. (2004). An empirical investigation of the relationship between strategic performance measurement systems, role clarity, psychological empowerment and work outcomes. Retrieved March 1, 2004, from http://ssrn.com/abstract $=567602$

Halpern, R. S. (1961). Employee unionization and foremen's attitudes. Administrative Sciences Quarterly, 6, 73-88.

Harrison, E. L. (1982). Training supervisors to discipline effectively. Training \& Development Journal, 36(11), 111-113.

Hoegl, M., \& Gemuenden, H. G. (2001). Teamwork quality and the success of innovative projects: A theoretical concept and empirical evidence. Organization Science, 12(4), 435-449.

Holzbach, R. L. (1978). Rater bias in performance ratings: Superior, self, and peer ratings. Journal of Applied Psychology, 63, 579-588.

Hossiep, R., \& Paschen, M. (1998). BIP: Bochumer Inventar zur berufsbezogenen Persönlichkeitsbeschreibung [BIP: Bochum Inventory for Job-Related Personality Description]. Göttingen: Hogrefe.

Ichniowski, C., Kochan, T. A., Levine, D., Olson, C., \& Strauss, G. (1996). What works at work: Overview and assessment. Industrial Relations, 35, 356374.

International Labour Office. (2002). Supporting workplace learning for high performance working. Retrieved March 1, 2004, from http://www.ilo.org/public/english/employment/skills/workplace/index.htm 
Jackson, S. E., \& Schuler, R. S. (1985). A meta-analysis and conceptual critique of research on role ambiguity and role conflict in work settings. Organizational Behavior \& Human Decision Processes, 36(1), 16-78.

Javidan, M. (1995). Superior and subordinate gender and the acceptance of superiors as role models. Human Relations, 48(11), 1271-1284.

Kirchner, W. K. (1965). Relationships between supervisory and subordinate ratings for technical personnel. Journal of Industrial Psychology, 3, 5760.

Klagge, J. (1998). Self-perceived development needs of today's middle managers. Journal of Management Development, 17(7), 481-491.

Kleinau, T. (2002). Entwicklung von Führungskompetenz für Meister bei Volkswagen [Development of leadership competence for foremen at Volkswagen]. Unternehmensberater, 8(3), 62-65.

Klimoski, R. J., \& London, M. (1974). The role of the rater in performance appraisal. Journal of Applied Psychology, 59, 445-451.

Latham, G. P., Fay, C. H., \& Saari, L. M. (1979). The development of behavioral observation scales for appraising the performance of foremen. Personnel Psychology, 32(2), 299-311.

Lawler, E. E. (1967). The multitrait-multirater approach to measuring managerial job performance. Journal of Applied Psychology, 51, 369-381.

Levine, D. I., \& D’Andrea Tyson, L. (1990). Participation, productivity, and the firm's environment. In A. S. Blinder (Ed.), Paying for productivity (pp. 183-236). Washington, DC: Brookings Institution.

Levine, E. L., Flory, A., \& Ash, R. A. (1977). Self-assessment in personnel selection. Journal of Applied Psychology, 62, 428-435.

Lowe, J. (1993). Manufacturing reform and the changing role of the production supervisor: The case of the automobile industry. Journal of Management Studies, 30(5), 739-758. 
Mabe, P. A. III, \& West, S. G. (1982). Validity of self-evaluation of ability: A review and meta-analysis. Journal of Applied Psychology, 67, 280-296.

Manz, C. C., \& Sims, H. P. (1987). Leading workers to lead themselves: The external leadership of self-managing work teams. Administrative Science Quarterly, 32(3), 106-128.

Martin, R., \& Wall, T. D. (1989). Attentional demand and cost responsibility as stressors in shopfloor jobs. Academy of Management Journal, 32(1), 6986.

Mason, G. (2000). Production supervisors in Britain, Germany and the United States: Back from the dead again? Work, Employment and Society, 14, $625-645$.

McEnery, J., \& McEnery, J. M. (1987). Self-rating in management training needs assessment: A neglected opportunity? Journal of Occupational Psychology, 60(1), 49-60.

McGrath, J. E. (1976). Stress and behaviour in organizations. In M. D. Dunnette (Ed.), Handbook of industrial and organisational psychology (pp. 13601395). Chicago: Rand McNally.

Messe, L. A., Kerr, N. L., \& Sattler, D. N. (1992). "But some animals are more equal than others": The supervisor as a privileged status in group contexts. In S. Worchel, W. Wood \& J. A. Simpson (Eds.), Group process and productivity (pp. 203-223). Newbury Park: Sage.

Meyer, H. H. (1980). Self-appraisal of job performance. Personnel Psychology, 33, 291-295.

Morano, R. (1973). Determining organizational training needs. Personnel Psychology, 26, 479-487.

Morrison, E. W., \& Bies, R. J. (1991). Impression management in the feedbackseeking process: A literature review and research agenda. Academy of Management Review, 16, 522-541.

Nethero, S. (1983). Supervisory training: A blueprint for research and testing in program development. Training \& Development Journal, 37(3), 21-25. 
Olivero, G., Bane, K. D., \& Kopelman, R. E. (1997). Executive coaching as a transfer of training tool: Effects on productivity in a public agency. Public Personnel Management, 26(4), 461-469.

Osterman, P. (2000). Work organization in an era of restructuring: Trends in diffusion and impacts on employee welfare. Industrial and Labor Relations Review, 53, 173-196.

Parker, J. W., Taylor, E., Barrett, R., \& Martens, L. (1959). Rating scale content: III. Relationship between supervisory- and self-ratings. Personnel Psychology, 39, 497-523.

Petty, M. M., McGee, G. W., \& Cavender, J. W. (1984). A meta-analysis of the relationship between individual job satisfaction and individual performance. Academy of Management Review, 9, 712-721.

Pietruschka, S. (2003). Führung selbstregulierter Arbeitsgruppen [Leadership of self-regulated work groups]. München: Rainer Hampp Verlag.

Posner, B. Z., \& Kouzes, J. M. (1990). Leadership practices: An alternative to the psychological perspective. In K. E. Clark \& M. B. Clark (Eds.), Measures of leadership (pp. 205-215). West Orange, NJ: Leadership Library of America.

Rauen, C. (1999). Coaching: Innovative Konzepte im Vergleich [Coaching: Innovative concepts in comparison]. Göttingen: Verlag für Angewandte Psychologie.

Sandwith, P. (1993). A hierarchy of management training requirements: The competency domain model. Public Personnel Management, 22(1), 43-62.

Sawyer, J. E. (1992). Goal and process clarity: Specification of multiple constructs of role ambiguity and a structural equation model of their antecedents and consequences. Journal of Applied Psychology, 77, 130142.

Schmidt-Braße, U., Rätz, C., \& Heier, J. (2001). Bildungscontrolling am Beispiel der Meisterqualifizierung: Weiterbildungscontrolling im Rahmen des "Meister-Entwicklungs-Programm" der STAHLwerke BREMEN 
[Controlling of personnel development, considering as example the qualification of foremen: Controlling of personnel development in the context of the "Foremen Development Programme" of the Steelworks Bremen]. Personalführung, 34(11), 66-72.

Schreyögg, A. (1995). Coaching: Ene Einführung für Praxis und Ausbildung [Coaching: An introduction for practice and training]. Frankfurt/Main: Campus.

Sheldrake, P., \& Saul, P. (1995). Change and the first line manager: A study of the changing role and skills of first line managers. In D. Karpin (Ed.), Enterprising nation: Renewing Australia's managers to meet the challenges of Asia-Pacific century (Report of the Industry Task Force on Leadership and Management Skills, vol. 1, chap. 16, pp. 665-711). Canberra: Australian Government Publishing Service.

Shipper, F., \& White, C. S. (1999). Mastery, frequency, and interaction of managerial behaviors relative to subunit effectiveness. Human Relations, 52(1), 49-66.

Shrauger, J. S., \& Osberg, T. M. (1981). The relative accuracy of self-predictions and judgements by others in psychological assessments. Psychological Bulletin, 90, 322-351.

Spies, R. (2004). "Coaching ist keine Führungsaufgabe" ["Coaching is not a leadership task"]. Personalführung, 37(1), 26-31.

Stahl, G. K., \& Marlinghaus, R. (2000). Coaching von Führungskräften: Anlässe, Methoden, Erfolg. Ergebnisse einer Befragung von Coaches und Personalverantwortlichen [Coaching of managers: Reasons, methods, success. Results of a survey of coaches and human resource managers]. Zeitschrift Führung und Organisation, 69(4), 199-207.

Stewart, G. L., \& Manz, C. C. (1995). Leadership for self-managing work teams: A typology and integrative model. Human Relations, 48, 747-770.

Thornton, G. C. III (1968). The relationship between supervisory and selfappraisals of executive performance. Personnel Psychology, 21, 441-455. 
Thornton, G. C. III (1980). Psychometric properties of self-appraisals of job performance. Personnel Psychology, 33, 263-271.

Trost, A., Jöns, I., \& Bungard, W. (1999). Mitarbeiterbefragung [Employee survey]. Augsburg: WEKA..

Tubre, T. C., \& Collins, J. M. (2000). Jackson and Schuler (1985) revisited: A meta-analysis of the relationships between role ambiguity, role conflict, and job performance. Journal of Management, 26(1), 155-169.

Vettermann, B., \& Dorando, M. (2003). Nachhaltige Entwicklungsprozesse für die Zielgruppe Werkstattführungskräfte: Nachhaltige Personalentwicklung im Rahmen eines langfristig angelegten Trainings- und Beratungskonzepts [Sustainable development processes for the target group of workshop leaders: Sustainable personnel development in the context of a long-term concept of training and consultation]. Personalführung, 36(7), 52-59.

Wales, S. (2003). Why coaching? Journal of Change Management, 3(3), 275282.

Wasylyshyn, K. M. (2003). Executive coaching: An outcome study. Consulting Psychology Journal: Practice \& Research, 55(2), 94-106.

Wilson, C. L., O'Hare, D., \& Shipper, F. (1990). Task cycle theory: The process of influence. In K. E. Clark \& M. B. Clark (Eds.), Measures of leadership (pp. 185-203). West Orange, NJ: Leadership Library of America.

Wolf, E., \& Zwick, T. (2002). Reassessing the impact of high performance workplaces (ZEW Discussion Paper No. 02-07). Mannheim: ZEW.

Yammarino, F. J., \& Bass, B. M. (1990). Long-term forecasting of transformational leadership and its effects among naval officers: Some preliminary findings. In K. E. Clark \& M. B. Clark (Eds.), Measures of leadership (pp. 151-170). West Orange, NJ: Leadership Library of America.

Yukl, G., Wall, S., \& Lepsinger, R. (1990). Preliminary report on validation of the Managerial Practices Survey. In K. E. Clark \& M. B. Clark (Eds.), 
Measures of leadership (pp. 223-237). West Orange, NJ: Leadership Library of America. 